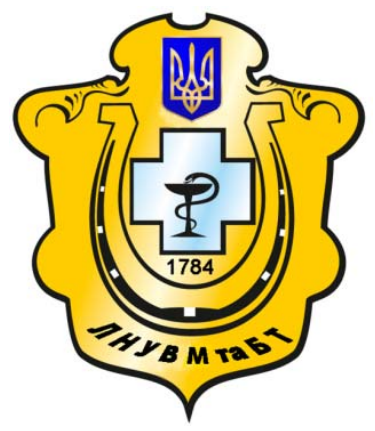

Науковий вісник Львівського національного університету ветеринарної медицини та біотехнологій імені С.3. Гжицького

Scientific Messenger of Lviv National University of Veterinary Medicine and Biotechnologies named after S.Z. Gzhytskyj

doi:10.15421/nvlvet7725

ISSN 2518-7554 print

ISSN 2518-1327 online

$\underline{\text { http://nvlvet.com.ua/ }}$

УДК 636.6:612:636.5.087.7:577.1

\title{
Протеїновий і амінокислотний обмін у м'язах курчат-бройлерів кросу КОББ 500 на тлі застосування кормової добавки «Гумілід»
}

\author{
Є.О. Михайленко ${ }^{1}$, О.О. Дьомшина ${ }^{2}$, Л.М. Степченко ${ }^{1}$ \\ olga-d2009@ukr.net
}
${ }^{1}$ Дніпропетровский державний аграрно-економічний університет, вул. Сергія Сфремова, 25, Дніпро, 49027, Україна;
${ }^{2}$ Дніпровський національний університет імені Олеся Гончара, пр. Гагаріна, 72, Дніпро, 49010, Україна

\begin{abstract}
У статті наведені дані щңодо вивчення впливу кормової добавки «Гумілід» на показники протеїнового та амінокислотного обміну м'язів курчат-бройлерів кросу КОББ 500. Показано, щэо у птахів, яким у воду додавали «Гумілід», у водорозчинній, найбільша частка якої представлена цитозольними протеїнами, та мітохондріальній фракціях м'язів відбувалось підвищення кількості загального протеӥну. У гомогенаті м'язів загальна кількість протеӥну збільшувалась на 10\%, у водорозчинній та мітохондріальній на 20\%, щуо дає можливість твердити про стимуляцію синтезу саме водорозчинних протеїнів під впливом «Гуміліду» та стимулячії формування хондріому міоцитів. Також отримані дані можуть свідчити про інтенсифікацію процесів використання амінокислот для біосинтезу протеїну та адаптаційних прочесів, щуо підтверджено даними про підвищення активності гама-глутамілтранспептидази у мітохондріальній фракиіі м'язів у 2 рази, яка саме бере участь у транспорті амінокислот та глутатіону у мітохондрії, шо розглядається як захисний механізм. Показано підвищення активності аланінамінотрансферази у 3 рази у водорозчинній фракиї та одночасне зниження лактатдегідрогенази. Розрахунок співвідношення активності ЛДГ/АлАТ показав зміщення анаеробного шляху перетворення глюкози до глюкозо-аланінового ичикл, більш ефективного шляху відновлення та використання глюкози.
\end{abstract}

Ключові слова: курчата-бройлери, біологічно активна кормова добавка «Гумілід», АлАТ, АсАТ, ЛДГ, ГТП, ЛФ, протеїновий обмін

\section{Протеиновый и аминокислотный обмен в мышцах цыплят-бройлеров кросса КОББ 500 при использовании кормовой добавкой «Гумилид»}

\author{
Е.А. Михайленко ${ }^{1}$ О.О. Дьомшина ${ }^{2}$, Л.М. Степченко ${ }^{1}$ \\ olga-d2009@ukr.net \\ ${ }^{1}$ Днепропетровский государственный аграрно-экономический университет, \\ ул. Сергея Ефремова, 25, Днипро, 49027, Украина; \\ ${ }^{2}$ Днипровский национальный университет имени Олеся Гончара, \\ пр. Гагарина, 72, Днипро, 49010, Украина
}

В статье приведены данные по изучению влияния кормовой добавки «Гумилид» на показатели обмена белков и аминокислот в мышиах иъыплят-бройлеров кросса КОББ 500. Показано, что у птии, которым в воду добавляли «Гумилид», в водорастворимой, наибольшая доля которой представлена изитозольной фракцией, и митохондриальной фракииях мыши наблюдали увеличение количества общего протеина. В гомогенате мыши общее количество протеина увеличивалось на 10\%, в водорастворимой и митохондриальной на 20\%, что дает возможность утверждать о стимуляции синтеза именно

Citation:

Myhaylenko, E.O., Dyomshyna, O.O., Stepchenko, L.M. (2017). Protein and amino acid metabolism in the muscles of broiler chickens cross COBB 500 during treatment feed additive «Humilid». Scientific Messenger LNUVMBT named after S.Z. Gzhytskyj, 19(77), 110-116. 
водорастворимых протеинов под влиянием «Гумилида» и стимуляции формирования хондриома миоцитов. Также полученные данные могут свидетельствовать об интенсификации процессов использования аминокислот для биосинтеза протеина и адаптационных процессов, что подтверждается данными о повышении в митохондриальной фракции мыши в 2 раза активности гамма-глутамилтранспептидазы, которая участвует в транспорте аминокислот и глутатиона в митохондрии, что рассматривается как защчттный механизм. Показано повьиение в 3 раза в водорастворимой фракции активности аланинаминотрансферазы и одновременное снижение лактатдегидрогеназы. Расчет соотношения активности ЛДГ/АЛТ показал смещуение анаэробного пути превращения глюкозы в сторону глюкозо-аланинового ичикла, более эффективного пути восстановления и использования глюкозы.

Ключевые слова: ц̧ыплята-бройлеры, биологически активная кормовая добавка «Гумилид», АлАТ, АсАТ, ЛДГ, ГТП, ЛФК, протеиновый обмен

\title{
Protein and amino acid metabolism in the muscles of broiler chickens cross COBB 500 during treatment feed additive «Humilid»
}

\author{
E.O. Myhaylenko ${ }^{1}$, O.O. Dyomshyna ${ }^{2}$, L.M. Stepchenko \\ olga-d2009@ukr.net \\ ${ }^{1}$ Dnipropetrovsk State Agrarian University of Economics, \\ st. Sergei Yefremov, 25, Dnipro, 49027, Ukraine; \\ ${ }^{2}$ Oles Gonchar Dnipro National University, \\ av. Gagarina, 72, Dnipro, 49010, Ukraine
}

The article presents data on the study of the impact of feed additives «Humilid» indicators on protein and amino acid metabolism of muscles of broiler chickens cross the COBB 500.The study tested that birds which additived «Humilid» the water increase in the muscles of total protein, which represented the largest share of the cytosolic and mitochondrial fractions. In homogenate of muscle, the total amount of protein increased by $10 \%$ in cytosolic and $20 \%$ in mitochondrial, which makes it possible to assert that stimulate the synthesis of cytosolic proteins is influenced «Humilid» and stimulated the formation chondriome of myocytes. Also, the data indicate an intensification of the use of amino acids for protein biosynthesis and adaptive processes, confirmed by increased in muscle mitochondrial fraction 2 times activity of gamma-glutamyltranspeptidase, which is involved in the transport of amino acids and glutathione in mitochondria that seen as a protective mechanism. The research has shown increased 3 times in cytosolic fraction activity of alanine aminotransferase and the simultaneous decrease in lactate dehydrogenase. Calculate the ratio activity of $L D H / A L T$ showed bias towards anaerobic conversion of glucose to glucose-alanine cycle, more efficient way of recovery and using of glucose.

Key words: broiler chickens, bioactive feed additive «Humilid», ALT, AST, LDH, GTP, ALP, protein metabolism

\section{Вступ}

Харчова цінність курчат-бройлерів полягає у якості м'яса. Особливо цінним є біле м'ясо, в якому майже 92\% легко перетравлюваних повноцінних протеїнів містять всі незамінні амінокислоти в оптимальному співвідношенні, багато Калію, Кальцію, Натрію, Фосфору, Заліза, Хлору (Birta and Burgu, 2011) та вітаміни А, Е, РР, групи В. Відомо, що важливою особливістю курчат-бройлерів є здатність їх до швидкого росту. Таке явище пов'язане з тим, що вони у 1,5-2 рази швидше, ніж інші тварини, перетворюють кормовий протеїн на харчовий. Саме тому протеїновий обмін $є$ індивідуальним показником, який відображає загальний метаболічний статус всього організму, є пріоритетним, первинним, широко специфічним та забезпечує вуглеводний i ліпідний обміни (Derho and Kolesnik, 2011; Stepchenko and Shulga, 2006). Крім того, контроль за станом протеїнового обміну в м'язах курчат бройлерного типу $\epsilon$ важливим етапом їхнього вирощування (Myhaylenko et al., 2014; Stepchenko, 2010, 2011). Даний тип обміну забезпечується метаболічними процесами за участю таких ензимів, як аспартатамінотрансфераза (АсАТ, КФ 2.6.1.1.) та аланінамінотрансфераза (АлАТ, КФ 2.6.1.2.), які є на перетині процесів катаболізму та анаболізму протеїнів і амінокислот. Крім того, важливу роль відіграє мембрано пов'язаний ензим $\gamma$-глутамілтранспептидаза (ГТП, К.Ф.2.3.2.2.), який каталізує перенесення $\gamma$-глутамільної групи внутрішньоклітинного трипептида глутатіону на транспортовану амінокислоту і подальший перенос комплексу в клітину i таким чином забезпечує не тільки транспорт амінокислот у клітину, а й саме клітину дуже важливим антиоксидантом. Ензим лактатдегідрогеназа (ЛДГ, КФ 1.1.1.27) опосередковано залучен до протеїнового обміну за рахунок постачання вуглецевого скелету кетокислот для синтезу амінокислот i забезпечення процесів енергією. Окрім того, ЛДГ є ензимною ланкою, яка пов'язана 3 глюкозо-аланіновим циклом, основним ензимом якого $\epsilon$ АлАТ. Саме співвідношення активності ЛДГ/АлАТ вказує на інтенсивність анаеробно/аеробного гліколізу, способу використання глюкози міоцитами та швидкості іiі відновлення у печінці, i, як наслідок, саме ефективність забезпечення м'язів енергією. Особливого значення це набуває для білих м'язів, які є збіднілими на мітохондрії, що вказує на превалювання анаеробного шляху перетворення глюкози.

Збільшення обсягів виробництва птахівничої продукції здійснюється не тільки за рахунок впровадження новітніх технологій і збільшення поголів'я птиці, а i шляхом введення до раціону біологічно активних добавок (Stepchenko, 2005; Bykov et al., 2012; Oliva 
and Gorshlov, 2013). 3 підвищенням продуктивності збільшується потреба в поживних речовинах кормів та питній воді, в тому числі й в макро- і мікроелементах, що беруть участь в складних біохімічних реакціях синтезу нуклеїнових кислот, білків, вуглеводів, ліпідів (Torshkov, 2010). Однак всмоктуватися і перетворюватися в організмі в метаболічно активну форму можуть тільки такі елементи, яким властива біологічна доступність, що визначається хімічною і фізичною формами, розміром часток, присутністю хелатних форм. До таких відносяться біологічно активні добавки на основі гумінових речовин, які широко використовуються у тваринництві. Наприклад, Гумілід (Buchko, 2013; Galuzina, 2012; Myhaylenko, 2015; Myhaylenko et al., 2016; Skorik, 2008; Stepchenko, 2011), Гумісол-Т-2 та Гідрогумат (Prihodchenko and Gladka, 2013; Stepchenko and Shulga, 2006, Stepchenko et al., 2008; Skorik, 2009), які розроблені та апробовані співробітниками науково-дослідної лабораторії з гумінових речовин ім. Л.А. Христєвої Дніпропетровського державного аграрно-економічного університету. Дані препарати відомі здатністю впливати на конверсію корму, ріст і якість м'яса сільськогосподарських тварин та своїми антидіарейними, знеболюючими, імуностимулюючими і антимікробними властивостями. 3 іншого боку, гумати здатні до хелатоутворення, а саме можуть утворювати стійку сполуку з мікроелементами та покращують їх засвоєння 3 корму і цим самим позитивно впливати на активність і синтез ензимів, виявляють високу адсорбційну здатність в шлунково-кишковому тракті (Stepchenko, 2010). Також важлива біологічна активність, яка властива гуматам - гормональна активність. Показано, що під дією гумінових речовин відбувається додатковий синтез АТФ, ДНК, РНК, зміна рівня сАМР, а також участь цих речовин в біосинтезі протеїнів, в т. ч. ензимів, і регуляції ензим-інгібіторних взаємодій при вивільненні додаткової енергії (Stepchenko et al., 2010; Stepchenko, 2011).

У літературі є свідчення щодо поліфункціонального впливу кормових добавок гумінової природи на різні органи, тканини і системи організму різних тварин (Buchko, 2013; Galuzina, 2012; Myhaylenko, 2015; Myhaylenko et al., 2016; Skorik, 2008; Stepchenko, 2011). Однак дані щодо стану протеїнового обміну в курчат-бройлерів кросу Кобб 500 у м'язовій тканині при додаванні до основного раціону «Гуміліду» відсутні. Окрім того, відсутні свідчення про функціонування мітохондрій у м'язовій тканині під впливом кормових біологічно активних добавок гумінової природи.

Мета роботи визначити вплив «Гуміліду» на рівень інтенсивності протеїнового та амінокислотного обмінів у водорозчинній та мітохондріальній фракціях м'язової тканини курчат бройлерного типу кросу КОББ 500.

\section{Матеріал і методи досліджень}

Експеримент проводили на курчатах бройлерного типу кросу Кобб 500 з 0 до 42-денного віку, яких утримували в стандартних умовах ТОВ «Птахокомп- лекс» Дніпровський» Нікопольського району Дніпропетровської області. Утримання птиці підлогове. Маніпуляції 3 тваринами проводилися відповідно до правил «Свропейської конвенції захисту хребетних тварин, які використовуються для експериментальних та інших наукових цілей» (м. Страсбург, 1985 р.). Птахи були розділені на 2 групи (по 23000 тварин у кожній): у пташнику № 1 були інтактні курчата (контроль), а у пташнику № 2 - курчата, яким у воду при випоюванні додавали «Гумілід» в оптимальній кількості за схемою запропонованою раніше (Myhaylenko, 2014). На 42 добу розвитку, після вибіркового зважування, відбирали по 5 курчат 3 середньою живою масою за групами тварин. Для отримання м'язової тканини проводили декапітацію курчат під етерним наркозом.

Дослідні фракції м'язової тканини отримували шляхом диференційного центрифугування гомогената. Водорозчинну фракцію отримували шляхом центрифугування гомогенату при швидкості 1000 об/хв протягом 10 хв. Мітохондріальну фракцію шляхом послідовного центрифугування водорозчинної фракції у середовищі, яке містило 0,25 М сахарози, 1 мМ ЕДТА, рН 7,4, протягом 10 хв кожне при 2000 об/хв для осадження клітинних уламків та 3000 об/хв для осадження мітохондрій. Отриманий осад, який містив мітохондрії, використовувували для подальшого відмивання у середовищі, що містило 0,25 М сахарози. Суспензію мітохондрій центрифугували 10 хв при 3000 об/хв. Супернатант відкидали, а отриманий осад мітохондрій ще двічі відмивали у середовищі, яке містило 0,25 М сахарози. Отримані мітохондрії використовували для подальших досліджень. Всі маніпуляції з мітохондріями проводили на льоду та при температурі не вище $4{ }^{\circ} \mathrm{C}$.

Отримані гомогенат, водорозчинну і мітохондріальні фракції м'язів використовували для визначення загальної кількості протеїну, активності аспартатамінотрансферази (АсАТ, КФ 2.6.1.1), аланінамінотрансферази (АлАТ, КФ 2.6.1.2), лактатдегідрогенази (ЛДГ, КФ 1.1.1.27), $\gamma$-глутамілтранспептидази (ГТП, КФ 2.3.2.2), лужної фосфатази (ЛФ, КФ 3.1.3.1) 3 використанням стандартних лабораторних методик тест-наборів (Фелісіт, Україна, м. Дніпро) за методами (Bertis et al., 2006; Young, 2001) згідно протоколу фірми виробника.

Статистичний аналіз отриманих результатів проводили за Манна-Уітні. Вірогідними відмінності вважали за $\mathrm{P}<0,05$.

\section{Результати та їх обговорення}

Протеїновий обмін є індивідуальним показником, який відображає загальний метаболічний статус всього організму, $є$ пріоритетним, первинним, широко специфічним та забезпечує вуглеводний та ліпідний обміни (Derho, 2011). Тому контроль за станом протеінового обміну в м'язах швидкозростаючих курчат бройлерного типу є важливим етапом їхнього вирощування та контролю якості їстівного м'яса (Myhaylenko et al., 2014; Stepchenko et al., 2010, Stepchenko, 2011). У гомогенаті м'язової тканини відбува- 
лось незначне збільшення (у межах 10\%) загальної кількості протеїну при застосуванні біологічно активної добавки «Гумілід» (рис. 1), у водорозчинній фракції цей показник збільшувався на 20\%, що вказує на стимуляцію гуміновими речовинами синтезу саме цитозольних протеїнів, які безпосередньо бере участь у метаболічних процесах. Відомий факт, що у білих м'язах міститься незначна кількість мітохондрій, тому синтез АТР, в основному, відбувається за рахунок гліколізу.

Додавання до питної води «Гуміліду» призводило до збільшення загального протеїну у мітохондріальній фракції майже на 20\%, що може свідчити про збільшення кількості мітохондрій у міоцитах. Таким чином, гумінові речовини здатні до стимуляції формування хондріому білих м'язів курчат-бройлерів та активізувати процеси енергозабезпечення, до яких залучені мітохондрії.

Ензимами, які беруть активну участь у протеїновому та амінокислотному обміні і $\epsilon$ на перетині їхніх процесів катаболізму та анаболізму, це трансамінази аспартатамінотрансфераза (АсАТ, КФ 2.6.1.1.) та аланінамінотрансфераза (АлАТ, КФ 2.6.1.2.).

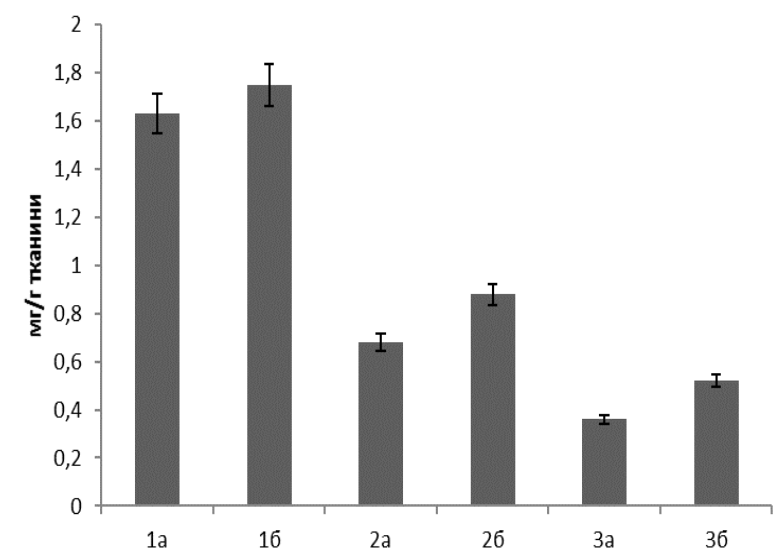

Рис. 1. Кількість загального протеїну у м'язах курчат-бройлерів кросу Кобб 550 у гомогенаті (1), водорозчинній фракції (2) та мітохондріальній (3) контрольної групи (а) та при випоюванні «Гумілідом» (б)

За дії «Гуміліду» у водорозчинній фракції відбувається підвищення активності АсAТ на $25 \%$ порівняно із контрольною групою птахів (рис. 2), у мітохондріальній фракції спостерігали незначне зростання активності ензиму.

Враховуючи той факт, що у птахів ензиматичний апарат циклу сечовини відсутній, основним кінцевим продуктом протеїнового обміну $є$ сечова кислота, у яку перетворюється шкідлива сполука аміак (Kalachnjuk et al., 2007). У мітохондріях АсАТ забезпечує цикл сечовини аспарагіновою кислотою. Таким чином, отримані експериментальні результати вказують, що у білих м'язах курчат-бройлерів АсАТ бере участь у постачанні субстратів для синтезу цитозольних протеїнів, а речовини гумінової природи стимулюють цей процес.
Особливої уваги заслуговують зміни активності АлАТ у дослідних фракціях м'язової тканини курчатбройлерів при додаванні у питну воду біологічно активної добавки «Гумілід» (рис. 3).

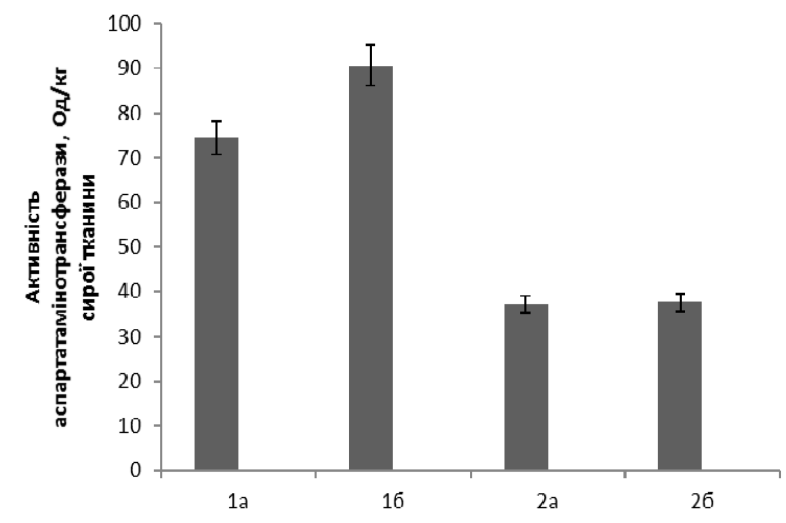

Рис. 2. Активність аспартатамінотрансферази у м'язах курчат-бройлерів кросу Кобб 550 у водорозчинній фракції (1) та мітохондріальній (2) контрольної групи (а) та при випоюванні «Гумілідом» (б)

Активність АлАТ у водорозчинній фракції збільшується у 3 рази порівняно 3 контрольною групою. Водночас у мітохондріальній фракції відбувалось пригнічення активності ензиму, що свідчить про участь АлАТ у цитозольних метаболічних процесах білих м'язів птахів.

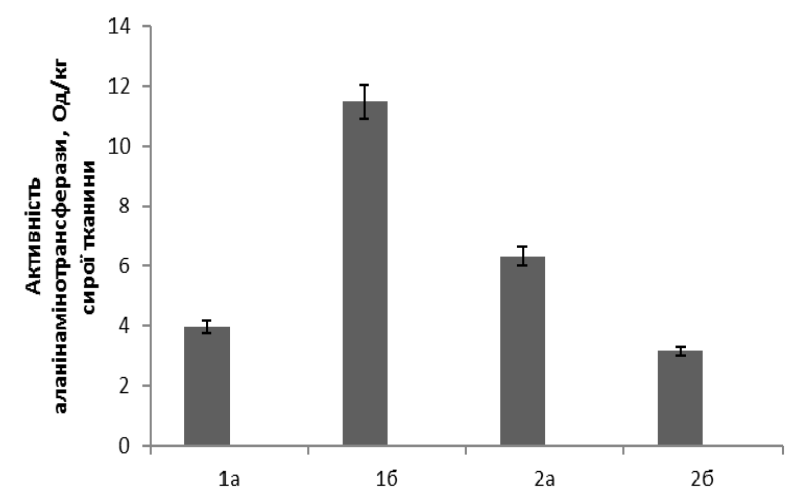

Рис. 3. Активність аланінамінотрансферази у м'язах курчат-бройлерів кросу Кобб 550 у водорозчинній фракції (1) та мітохондріальній (2) контрольної групи (а) та при випоюванні «Гумілідом» (б)

Суттєве підвищення активності АлАТ у білих м'язах за дії «Гуміліду» вказує на інтенсифікацію глюкозо-аланінового циклу, а саме перетворення пірувату, який є основним продуктом гліколізу у білих м'язах, на нешкідливу його транспортну форму аланін. В подальшому аланін може бути використаний на синтез протеїну в м'язах або синтезу глюкози у печінці, завдяки роботі глюкозо-аланінового циклу.

Також важливу роль у обміні протеїнів відіграє мембрано-пов'язаний ензим $\gamma$-глутамілтранпептидаза (ГТП, КФ 2.3.2.2.), який каталізує перенесення $\gamma$-глутамільної групи внутрішньоклітинного трипептида глутатіону на транспортовану амінокислоту і подальший перенос комплексу в клітину і таким чином забезпечує транспорт амінокислот та обмін глутатіону. 
Встановлено, що у водорозчинній фракції м'язової тканини відбувається невірогідне підвищення активності ГТП за умов застосування препарату гумінової природи (рис. 4).

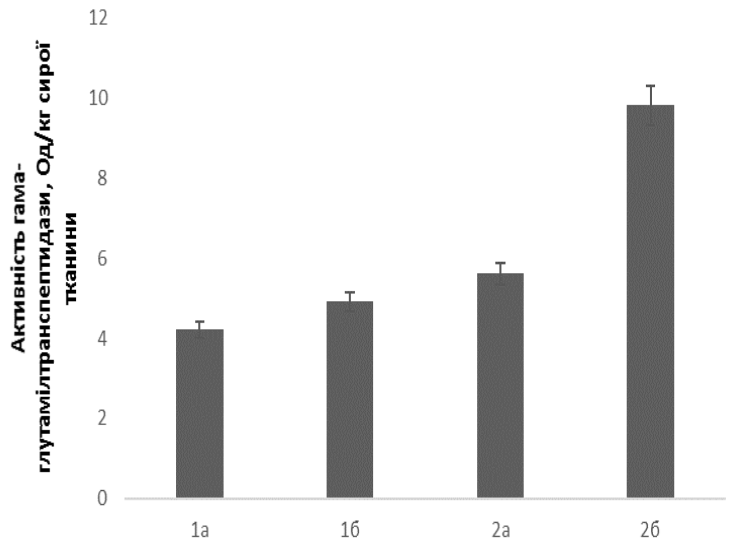

Рис. 4. Активність $\gamma$-глутамілтранспептидази у м'язах курчат-бройлерів кросу Кобб 550 у водорозчинній фракції (1) та мітохондріальній (2) контрольної групи (а) та при випоюванні «Гумілідом» (б)

Інша картина спостерігається у мітохондріальній фракції, де за експериментальних умов відбувалась активізація ГТП майже у 2 рази. По-перше, це вказує на активізацію транспорту амінокислот, які необхідні для синтезу протеїнів циклу Кребса, інформація про які закодована у мДНК, i, як наслідок - підвищується енергоефективність клітин. По-друге, мітохондрії $є$ основним місцем використання та запасання глутатіону у клітині (Hall, 1999), у транспорті якого безпосередньо бере участь ГТП. Отже, отримані дані вказують на інтенсифікацію процесів дихання клітини, що підвищує енергетичний потенціал, та адаптаційних процесів в умовах можливого впливу ксенобіотичних речовин. Окрім того, в роботі (Skorik, 2009) показано підвищення кількості глутатіону у крові та еритроцитах курей-несучок під впливом біологічно активної кормової добавки гумінової природи «Гідрогумат».

Лактатдегідрогеназа (ЛДГ, КФ 1.1.1.27) - це ензим, який бере участь у вуглецевому обміні та процесах забезпечення енергією клітин, особливо в анаеробних умовах та при фізичних навантаженнях. Перебуваючи на перетині шляхів метаболізму вуглеводів, ЛДГ бере участь в регуляції тонко збалансованих процесів катаболізму і анаболізму, анаеробного i aeробного гліколізу (Xu and Becker, 1998). Відомо, що існує 5 ізоферментів ЛДГ. У м'язах присутня ізоформа ЛДГ5 (ММMМ субодиниці) (Zimin, 2001), яка виявляє високу спорідненість до пірувату та перетворює його у лактат при нестачі оксигену в клітині. При випоюванні курчат-бройлерів «Гумілідом» відбувалось 5\% пригнічення активності ЛДГ у водорозчинній та мітохондріальній фракціях м’язів (рис. 5).

У сучасній науковій літературі є свідчення про механізм регуляції біохімічних процесів зворотною взаємодією «розчинних» ензимів із субклітинними структурами (Lushchak, 1998; Soloviev, 2013; Zimin, 2001). Таким чином, застосування «Гуміліду» може стимулювати зв'язування вільної ЛДГ із мембраною мітохондрій за рахунок регуляторних властивостей гумінових речовин, що і призводило до зниження іiі активності. Окрім того, ЛДГ опосередковано залучена до протеїнового обміну за рахунок постачання вуглецевого скелету кетокислот для синтезу амінокислот і забезпечення процесів енергією. Також ЛДГ є ензимом, який пов'язаний з глюкозо-аланіновим циклом, основним ензимом якого є АлАТ.

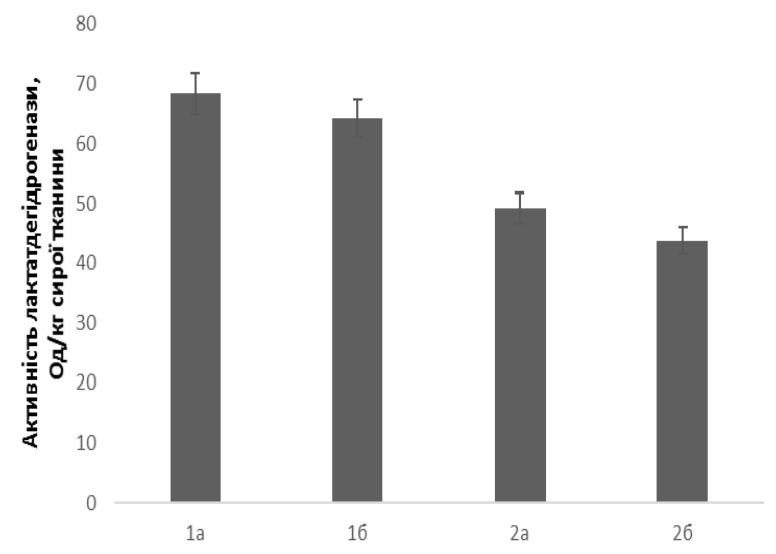

Рис. 5. Активність лактатдегідрогенази у м'язах курчат-бройлерів кросу Кобб 550 у водорозчинній фракції (1) та мітохондріальній (2) контрольної групи (а) та при випоюванні «Гумілідом» (б)

Саме співвідношення активності ЛДГ/АлАТ вказує на інтенсивність анаеробно/аеробного гліколізу та способу використання глюкози міоцитами та швидкості її відновлення у печінці i, як наслідок - ефективність забезпечення м'язів енергією. Таким чином, у контрольній групі курчат співвідношення активності ЛДГ/АлАТ складало 17/1, а при застосуванні «Гуміліду» цей показник знижувався до значення 6/1, що вказує на переключення метаболізму пірувату на глюкозо-аланіновий цикл. У мітохондріальній фракції контрольної групи співвідношення активності ЛДГ/АлАТ складало 8/1, а в експериментальній групі цей показник підвищувався до значення 14/1, що вказує на більш значущу роль ЛДГ у метаболічних процесах у мітохондріях. Особливого значення отримані дані набувають для білих м'язів, які є збіднілими на мітохондрії, а застосування «Гуміліду» стимулює превалювання шляху перетворення глюкози у піруват, який в умовах активації АлАТ (рис. 3) перетворюється у аланін. Також цей факт підтверджується активізацією АлАТ у печінці курчат-бройлерів за умов їхнього випоювання «Гумілідом» (Myhaylenko et al., 2016). Речовини, які здатні корегувати у білих м'язах процес перетворення пірувату у його менш токсичну транспортну форму аланін, порівняно із лактатом, $\epsilon$ перспективними регуляторами метаболічних процесів.

Загальновідомий факт, що активність лужної фосфатази у м'язах незначна. Даний ензим бере участь у фосфорному обміні, однак у білих м'язах провідна роль в цьому процесі відведена креатинінкіназі, активність якої в даному експерименті не досліджувалась. Отримані експериментальні дані вказують на порядок нижчу активність лужної фосфатази у м'язах порівня- 
но із печінкою (Myhaylenko et al., 2016). Однак простежується однакова тенденція до незначного, у межах 5\%, зниження активності ЛФ як у білих м'язах (рис. 6), так і в печінці курчат-бройлерів при додаванні до питної води «Гуміліду».

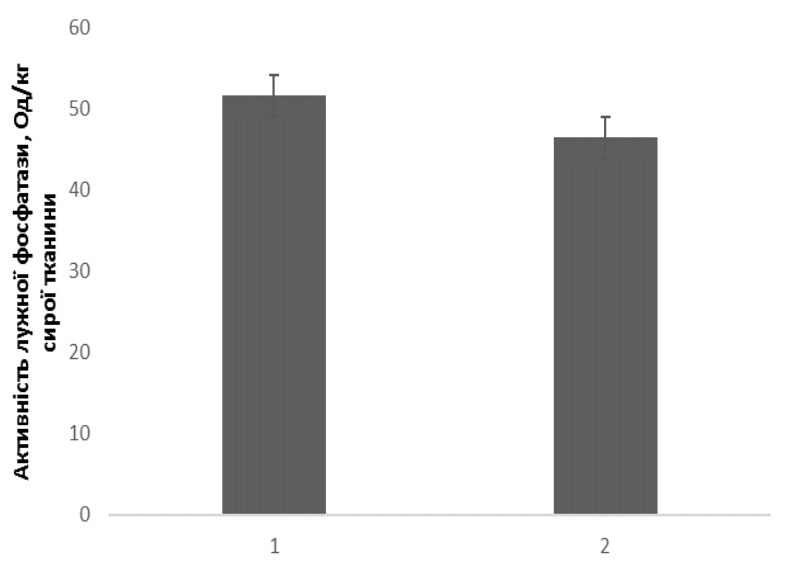

Рис. 6. Активність лужної фосфатази у м'язах курчат-бройлерів кросу Кобб 550 у водорозчинній фракції контрольної групи (1) та при випоюванні «Гумілідом» (2)

\section{Висновки}

Біологічно активна кормова добавка «Гумілід» стимулює протеїновий синтез, в основному за рахунок водорозчинної та мітохондріальної фракцій, активізує глюкозо-аланіновий цикл, що підтверджено даними щодо підвищення активності аланінамінотрансферази у печінці та м'язовій тканині та одночасного зниження активності лактатдегідрогенази у м'язах. Встановлено у мітохондріальній фракції м'язів інтенсифікацію $\gamma$-глутамілтранспептидази, яка забезпечує транспорт амінокислот у клітину та мітохондрії, а також забезпечує адаптацію клітини в умовах ксенобіотичного впливу.

Перспективи подальших досліджень. Техногенне забруднення навколишнього середовища, підвищення захворюваності сільськогосподарських птахів та, як наслідок, зниження продуктивності у тваринництві потребує пошуку шляхів подолання таких негативних явищ. Одним з таких є застосування кормових біологічно активних добавок гумінової природи, а саме «Гуміліду». Тому існує необхідність подальших досліджень в даному напрямку, спрямованих на дослідження взаємозв'язків, в тому числі кореляційних, між показниками, що характеризують протеїновій та амінокислотний обміни у курчат бройлерів в сироватці крові, а також тканинах печінки та грудних м'язів.

\section{Бібліографічні посилання}

Birta, G.O., Burgu, Ju.G. (2011). Tovaroznavstvo m'jasa. Navchal'nyj posibnyk. K., Centr navchal'noi' literatury, 164 (in Ukrainian).

Buchko, O.M. (2013). Vil'noradykl'ni procesy v organizmi porosjat za dii' guminovoi' dobavky, Biol. Tvarin. 1, 15, 27-33 (in Ukrainian).
Bykov, A.V., Bykova, L.A., Rahmatullin, Sh.G. (2012). Biohimicheskie i morfologicheskie izmenenija v krovi pticy pod vozdejstviem kormovogo faktora, Vestn. mjasnogo skotovodstva. 4, 78, 78-81(In Russian).

Galuzina, L.I. (2012). Vplyv kormovoi' dobavky «Gumilid» na kil'kisni ta jakisni pokaznyky m'jasnoi' produktyvnosti strausiv, Naukovo-tehnichnyj bjuleten'. Instytut biologii' tvaryn. 13, 1-2, 137-142 (in Ukrainian).

Derho, M.A., Kolesnik, E.A. (2011). Correlation of weight gain and the preservation of broilers ISA-15 cross-country with the level of blood biochemical parameters. Agricultural Vestnik Urals. 3, 27-29 (in Russian).

Zimin, Ju.V., Sjatkin, S.P., Berezov, T.T. (2001). Nadmolekuljarnaja reguljacija aktivnosti nekotoryh oksidoreduktaz kletki v norme i patologii. Vopr. Med. Himii. 47(3), 279-287 (In Russian).

Kalachnjuk, L., Mel'nychuk, D., Kalachnjuk, G. (2007). Aktyvnist' kljuchovyh enzymiv ornitynovogo cyklu u razi porushen' metabolizmu $\mathrm{v}$ klityni, Visnyk L'viv. Un-tu. Serija biologichna. 44, 37-42 (in Ukrainian).

Lushchak, V.I. (1998). Influence of Polyethylene Glycol on Lactate Dehydrogenase, Biochem. Mol. Biol. Int. 44, 425-431 (in Ukrainian).

Myhaylenko, E.A., Griban, V.G., Stepchenko, L.M. (2014). Osobennosti belkovogo obmena u cypljatbrojlerov krossa Kobb-500 pri vkljuchenii v racion Gumilida, Sbornik tezisov: Guminovye veshhestva i drugie biologicheski aktivnye soedinenija v sel'skom hozjajstve, Moskva. 55-58 (In Russian).

Myhaylenko, E.O. (2015). Gematologichni ta biohimichni pokazniki krovi kurchat-brojleriv pri vvedenni do ïh racionu biologichno aktivnoï kormovoï dobavki «Gumilid» z vodoju, Naukovo-tehnichnij bjuleten' NDC biobezpeki ta ekologichnogo kontrolju resursiv APK. 3(4), 132-135 (in Ukrainian).

Myhaylenko, E.O., D'omshina, O.O., Ushakova, G.O., Griban, V.G., Stepchenko, L.M. (2016). Vplyv kormovoi' dobavky «Gumilid» na pokaznyky protei'novogo i aminokislotnogo obminiv i kurchatbrojleriv krosu Kobb 500, Biol. Tvaryn. 4, 66-71 (in Ukrainian).

Myhaylenko, E.O., D'omshina, O.O., Ushakova, G.O., Stepchenko, L.M. (2016). Efektivnist' antioksidantnoi' sistemi pechinki brojleriv krosu Kobb-500 pri vipojuvanni prirodnimi biologichno aktivnimi dobavkami na osnovi guminovih rechovin, Visnik Derzhavnogo agrarno-ekonomichnogo universitetu. 4, 42, 120-125 (in Ukrainian).

Oliva, T.V., Gorshkov, G.I. (2013). Ispol'zovanie preparata «Seleksen» pri vyrashhivanii cypljatbrojlerov, Vestnik MGOU. Serija «Estestvennye nauki»». 1, 28-33 (In Russian).

Pryhodchenko, V.O., Gladka, N.I. (2013). Efektyvnist' vykorystannja biologichno aktyvnoi' kormovoi' dobavky gumisol v racionah kurchat-brojleriv, Naukovyj visnyk LNUVMBT imeni S.Z. Gzhyc'kogo. 15, 3(57), 3, 185-191 (in Ukrainian).

Skoryk, M.V. (2008). Vzaymosvjaz' funkcyonal'nogo sostojanyja jeritrocitov y mykrojelementov $\mathrm{v}$ pecheny kur-nesushek pod vlyjanyem gumynovyh kormovyh 
dobavok razlychnogo proyshozhdenyja. Naukovyj visnyk LNUVMBT imeni S.Z. Gzhyc'kogo. 10, 3(38), 2, 190-197 (in Ukrainian).

Skoryk, M.V. (2009). Funkcional'nyj stan erytrocytiv i vmist mikroelementiv $u$ vnutrishnih organah kurejnesuchok za vplyvu rechovyn guminovoi' pryrody. avtoref. dysert. na zdobuttja nauk.stup.kand. veter. nauk za special'nistju 03.00.13 - fiziologija ljudyny i tvaryn. L'vivs'kyj nacional'nyj universytet veterynarnoi' medycyny ta biotehnologij imeni S.Z. G'zhyc'kogo (in Ukrainian).

Solov'eva, A.G., Ulanova, A.A., Zymyn, Ju.V. (2013). Ocenka vzaymodejstvyja nadmolekuljarnogo klastera «alkogol'degydrogenaza-laktatdegydrogenaza» s membranoj mytohondryj pecheny krys, Fundamental research. 8, 1400-1405 (In Russian).

Stepchenko, L.M. (2005). Mehanyzmy formyrovanyja byoprodukcyy u bystrorastushhej ptycy pod vlyjanyem preparatov gumynovoj pryrody, Visnyk Dnipropetrovs'kogo derzhavnogo agrarnogo universytetu. 2, 237-241(in Ukrainian).

Stepchenko, L.M., Shul'ga, O.V. (2006). Sklad lipidiv gepatocytiv molodyh shuriv za umov alimentarnogo vplyvu gidrogumata, Visnyk Dnipropetrovs'kogo derzhavnogo agrarnogo universytetu. 1, 86-89 (in Ukrainian)

Stepchenko, L.M., Losjeva, Je.O., Skoryk, M.V., Goncharova, O.V. (2008). Funkcional'nyj stan organizmu produktyvnoi' ptyci za dii' gidrogumatu, Visnyk Dnipropetrovs'kogo derzhavnogo agrarnogo universytetu. 2, 99-103 (in Ukrainian).

Stepchenko, L.M. (2010). Reguljatorni mehanizmy dii' biologichno aktyvnyh rechovyn guminovoi' pryrody na organizm produktyvnoi' ptyci, Fiziologichnyj zhurnal. 56, 2, 306 (in Ukrainian).
Stepchenko, L.M., Galuzina, L.I. (2011). Vplyv biologichno aktyvnoi' kormovoi' dobavky «Gumilid» na m'jasnu produktyvnist' chornogo afrykans'kogo strausa za jogo promyslovogo vyroshhuvannja, Visnyk Dnipropetrovs'kogo derzhavnogo agrarnogo universytetu. 1, 165-171 (in Ukrainian).

Stepchenko, L.M. (2011). Byologychesky aktyvnye veshhestva gumynovoj pryrody kak reguljatory gomeostaza ptycy. Materyaly VII Mezhdunarodnoj konferencyy «Radostim» «Fytogormony, gumynovye veshhestva y drugye byoracyonal'nye pestycydy $\mathrm{v}$ sel'skom hozjajstve». Mynsk, 164-167 (in Belarus).

Stepchenko, L.M., Losjeva, Je.O., Jefimov, V.G. (2010). Aktyvnist' travnyh fermentiv kurej-nesuchok za dii' kormovoi' dobavky guminovoi' pryrody, Naukovyj visnyk nacional'nogo universytetu bioresursiv i pryrodokorystuvannja Ukrai'ny. 151, 1, 274-279 (in Ukrainian).

Torshkov, A.A. (2010). Influence of arabinogalactan on productive qualities of broiler chickens, Proceedings of the Orenburg State Agrarian University. 3, 27(1), 203-205 (In Russian).

Bertis, S.A., Ashvud, E.R., Bruns, D. (2006). Textbook of Clinical Chemistry and Molecular Diagnostics, 4Th ed.Filadelfiya, PA: WB Saunders, 549.

Hall, A.G. (1999).The role of glutathione in the regulation of apoptosis, European Journal of Clinical Investigation. 29, 238-245.

Xu, K.Y., Becker, L.C. (1998). Ultrastructural localization of glycolytic enzymes on sarcoplasmic reticulum vesticles, J. Histochem. Cytochem. 46(4), 419-427.

Young, D.S. (2001). Effects of disease on clinical laboratory test, $4^{\text {th }}$ ed. AACC Press, 1850.

Стаття надійшла до редакиії 23.03.2017 